\title{
Experiência na editoração cientifica da Journal of Nursing and Health
}

\section{Adrize Rutz Porto, Sidnéia Tessmer Casarin, Juliane Portella Ribeiro, Clarice Alves Bonow}

O Journal of Nursing and Health (JONAH) é vinculada a Universidade Federal de Pelotas (UFPel), sul do Brasil. É gratuita, da área das Ciências da Saúde, quadrimestral, com início desde 2011.

Objetiva-se com este trabalho relatar a experiência na editoração científica do JONAH, com vistas ao resgate histórico e orientação para lançar novas metas para a qualificação da revista.

No relato de experiência, descreve-se a visão das editoras atualmente responsáveis pela revista sobre a caminhada desta na comunicação científica na área da saúde e enfermagem. Essa equipe editorial está há 18 meses atuando na gestão da revista:

$\rightarrow$ possui regimento que normatiza o funcionamento e a estrutura da revista;

$\rightarrow$ fluxo contínuo de recebimento e publicação;

$\rightarrow$ Editor-chefe tem redução de 2 horas de ensino na graduação;

$\rightarrow$ avaliação dos artigos é por pares cegos de autor e avaliador;

$\rightarrow$ a equipe tem mais três docentes e 18 pós-graduandos. Os pós-graduandos auxiliam na revisão de conformidade dos artigos com as normas da revista (prazo de seis dias) para cada artigo;

$\rightarrow$ os pós-graduandos são selecionados, podendo ficar após a condição de egresso, se tiver interesse e disponibilidade;

$\rightarrow$ Revista não tem orçamento e publica em acesso aberto, não cobra taxas/encargos para os autores, nem de submissão de artigos e nem de processamento e publicação.

$\rightarrow$ a ausência de orçamento não impede o funcionamento da revista, visto que há a colaboração da Direção da Faculdade, da Coordenação da Pós-Graduação e da Coordenação das Bibliotecas, com a estrutura, os materiais, capacitação das editoras, disponibilidade de pós-graduandos e DOls, bem como a atuação das editoras para a realização de todo fluxo editorial, desde a submissão à alimentação das publicações em bases de dados; $\rightarrow$ JONAH adota preservação digital e verificação de similaridade e plágio nos artigos;

$\rightarrow$ divulga os trabalhos em mídias sociais, Twitter e Facebook;

$\rightarrow$ a indexação em bases de dados e repositórios foi ampliada, sendo as últimas, CINAHL, DOAJ;

$\rightarrow$ em 2018, a endogenia, tanto local, quanto regional foi reduzida de $60 \%$ para $30 \%$. Também diminuiu endogenia institucional, tendo 20 membros do conselho editorial internacional de países dos EUA, Colômbia, Costa Rica, Londres, Itália, Espanha, etc. No conselho editorial nacional, 45 membros, sendo que apenas 30\% são do RS.

\section{DESAFIOS:}

1) recebimento de artigos originais externos ao RS, para superar a endogenia regional;

2) qualidade das avaliações por pares e número de pareceristas disponíveis.

METAS:

1) Indexação EBSCO e SCOPUS;

2) Tradução dos artigos para língua inglesa;

- parceria da revista com um projeto de extensão do Centro de Letras da Universidade para alcançar a avaliação de fator de impacto da revista.

Assim, o compartilhamento desse relato de experiência poderá ser útil para que editores de outras instituições federais de ensino conheçam particularidades de outras revistas e também fomenta debates sobre editoração no país. 